\title{
POLA DISTRIBUSI MAKROALGA PADA EKOSISTEM LAMUN DAN KARANG DI PERAIRAN DESA WAWATU KECAMATAN MORAMO UTARA
}

\author{
Makroalgae Distributoin Pattern in Seagrass and Coral Ecosystems in the Wawatu Village \\ Waters North Moramo District
}

\author{
${ }^{1}$ Winda Sari Kalani, Emiyarti ${ }^{2}$, dan $\operatorname{Ira}^{3}$ \\ ${ }^{1}$ Mahasiswa Ilmu Kelautan, Fakultas Perikanan dan Ilmu Kelautan Universitas Haluoleo \\ Jl. H.E.A Mokodompit Kampus Hijau Bumi Tridharma Anduonohu Kendari 93232, Telp/Fax: (0401) 3193782 \\ ${ }^{2}$ Surel: emiyarti70@gmail.com \\ ${ }^{3}$ Surel: irafpikunhalu@gmail.com
}

\begin{abstract}
Abstrak
Makroalga merupakan sumber daya hayati laut yang memiliki nilai ekonomis penting, antara lain sebagai bahan makanan, obat-obatan dan bahan industri. Makroalga dapat dijumpai pada rataan terumbu karang dan lamun dimana masih terdapat sinar matahari yang cukup untuk melakukan fotosintesis. Penelitian ini dilakukan dengan tujuan untuk mengetahui distribusi magroalga pada ekosistem lamun dan karang di Perairan Desa Wawatu Moramo Utara. Penelitian ini dilaksanakan pada bulan November 2018-April 2019, yang meliputi pengambilan data dan pengelolaan data penelitian. Pengambilan data dilakukan dengan menggunakan metode transek kuadrat $(1 \mathrm{x} 1 \mathrm{~m})$ dan diletakkan pada jarak $10 \mathrm{~m}$ dari suatu kuadrat ke kuadrat berikutnya. Pengambilan data tiap stasiunnya terdiri dari 3 sub stasiun. Jenis makroalga yang ditemukan pada tiap stasiun yaitu 1 jenis kelas Chlorophyta (Codium decorticatum), 4 jenis kelas Phaeophyta (Padina australis, Dictyota dichotoma, Sargassum polycytum, Turbinaria ornota) dan 7 jenis kelas Rhodophyta (Gracilaria dura, Gracilaria ferguisonni, Gracilaria coronopifolia, Gracilaria textori, Amphiroa fraglilissima, Sympiloca hydnoides, Spermothamnion sp.). Kepadatan makroalga yang diperoleh berkisar antara 21,4$35,633 \mathrm{ind} / \mathrm{m}^{2}$, indeks keanekaragaman (H') berkisar antara 1,824-1,864, indeks keseragaman antara 0,896-0,937, indeks dominansi antara 0,186-0,180 dan distribusi jenis makroalga antara 0,168-0,412. Pola distribusi makroalga pada ekosistem lamun dan karang yaitu merata.
\end{abstract}

Kata Kunci: Makroalga, Distribusi Jenis Makroalga, Perairan Desa Wawatu

\begin{abstract}
Macroalgae is a marine biological resource that has important economic values, including food, medicine, and industrial materials. Macroalgae can be found on the coral reefs and seagrasses where there is enough sunlight to carry out photosynthesis. This research was conducted to determine the distribution of macroalgae in seagrass and coral ecosystems in the waters of Wawatu Village, North Moramo. This research was conducted in November 2018-April 2019, which included data retrieval and management of research data. Data retrieval was done using the quadratic transect method $(1 \mathrm{x} 1 \mathrm{~m})$ and placed at a distance of $10 \mathrm{~m}$ from a square to the next square. Data collection for each station consists of 3 substations. The species of macroalgae found at each station, namely 1 species of Chlorophyta (Codium decorticatum), 4 species of Phaeophyta (Padina australis, Dictyotadichotoma, Sargassum polycystum, Turbinaria ornata), and 7 species of class Rhodophyta (Gracilaria dura, Gracilaria fergusonii, Gracilaria coronopifolia, Gracilaria textorii, Amphiroa fragilissima, Symploca hydnoides, Spermothamnion sp.). The macroalgae density obtained ranged from $21,4-35,633 \mathrm{ind} / \mathrm{m}^{2}$, the diversity index $\left(\mathrm{H}^{\prime}\right)$ ranged from $1,824-1,864$, the uniformity index between 0,896 0,937 , dominance index between $0,186-0,180$ and the distribution of macroalgae species between $0,168-0,412$. The pattern of macroalgae distribution in seagrass and coral ecosystems were evenly distributed.
\end{abstract}

Keywords: Macroalgae, Distribution of Macroalgae Types, Waters of Wawatu Village

\section{Pendahuluan}

Makroalga merupakan tumbuhan tingkat rendah yang tidak dapat di bedakan antara akar, batang dan daun. Mengandung klorofil dan dapat berfotosintesis serta memiliki alat reproduksi yang sederhana (Sinyo dan Somardayo, 2013). Makroalga merupakan salah satu sumber daya hayati yang sangat potensial untuk dikembangkan dan tersebar luas di wilayah perairan Indonesia terutama di daerah pesisir intertidal.

Makroalga memiliki nilai ekonomis penting sebagai produk alam komoditi yang sangat baik untuk dikembangkan mengingat kandungan kimia yang di milikinya. Makroalga dimanfaatkan secara luas baik dalam bentuk bahan material 
mentah maupun sebagai olahan. Dalam bentuk material mentah digunakan sebagai lalapan, sayur, manisan dan asinan. Pemanfaatan dalam bentuk olahan makroalga antara lain berupa makanan, kesehatan (obat-obatan) dan bahan penambah dalam berbagai industri misalnya industri makanan, minuman, bioteknologi dan tekstil. Dari segi biologis, meingkatkan produkivitas primer, penyerapan bahan polutan, penghasil bahan organik dan penghasil oksigen bagi organism akuatik di lingkungan perairan (Bold dan Wynne, 1985).

Perairan Desa Wawatu Kecamatan Moramo Utara merupakan daerah yang memiliki potensi sumberdaya hayati dan makroalga yang cukup padat dimana makroalga ini banyak di temukan di daerah padang lamun dan daerah terumbu karang yang masih mendapatkan sinar matahari untuk melakukan proses fotosintesis. Keberadaan makroalga pada Perairan Desa Wawatu ini sangat penting dimana dapat melindungi dan sebagai tempat mencari makan bagi organisme yang membutuhkannya. Hasil survei menunjukan bahwa daerah memiliki makroalga yang berada di ekosistem lamun dan rataan terumbu karang yang belum teridentifikasi. Oleh karena itu maka perlunya dilakukan penelitian mengenai Pola Distribusi Makroalga pada Ekosistem Lamun dan Karang di Perairan Desa Wawatu Kecamatan Konawe Selatan.

\section{Bahan dan Metode}

Penelitian ini telah dilaksanakan dari bulan November 2018-April 2019, di Perairan Desa Wawatu, Kecamatan Moramo Utara, Kabupaten Konawe Selatan, Provinsi Sulawesi Tenggara. Peta lokasi penelitian dilihat pada Gambar 1.

Observasi lapangan dilakukan dengan tujuan untuk mengetahui gambaran umum lokasi penelitian yang ada di Perairan Desa Wawatu. Penentuan titik stasiun ini ditentukan sebanyak dua stasiun berdasarkan keberadaan makroalga. Stasiun I, terletak pada daerah Lamun dengan posisi geografis $4^{\circ}$ 5'37.37"'LS dan 122³9'23.35"BT di Perairan Desa Wawatu. Stasiun II, terletak pada daerah Terumbu Karang dengan posisi geografis $4^{\circ}$ 5'39.13"LS dan 122³9'23.67"BT di Perairan Desa Wawatu.

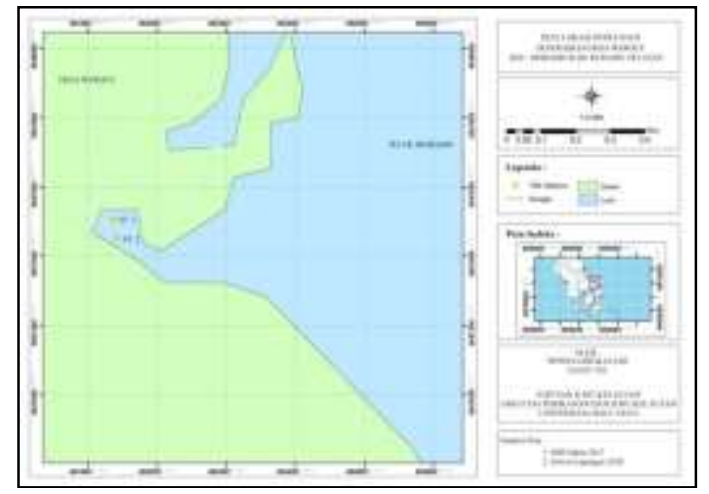

Gambar 1. Peta Lokasi Penelitian

Pengambilan sampel makroalga dilakukan pada setiap stasiun pengamatan, diperoleh dengan menggunakan metode transek garis. Transek garis yang dibentangkan tegak lurus dari garis pantai ke arah laut sepanjang $100 \mathrm{~m}$. Masing-masing garis transek diletakan transek kuadrat $(1 \mathrm{~m} \times$ $1 \mathrm{~m}$ ) dengan jarak ukur kuadran $10 \mathrm{~m}$ dengan cara zig-zag atau (selang seling). Pengambilan data di setiap stasiunnya terdiri dari 3 sub stasiun.

Sampel makroalga yang terdapat di dalam transek dihitung jumlah per jenis (setiap individu atau tegakan) kemudian didokumentasikan dengan menggunakan kamera digital. Kemudian makroalga yang tidak dapat diidentifikasi dimasukkan kedalam plastik sampel dan diidentifikasi sesuai dengan panduan Jha et al. (2009), Setyobudiandi et al. (2009) dan www.aglabase.org.

Pengambilan sampel makroalga dilakukan pada saat air surut dan dibantu dengan alat dasar selam. Untuk data di karang menggunakan alat SCUBA. 
Pengambilan persentase tutupan lamun lamun dilakukan pada saat surut dengan metode transek garis dengan buku panduan Mckenzie et al. (2003). Transek garis yang dibentangkan tegak lurus dari garis pantai ke arah laut sepanjang 100 $\mathrm{m}$. Masing-masing garis transek diletakan transek kuadrat $(1 \mathrm{~m} \times 1 \mathrm{~m})$ dengan jarak ukur kuadran $10 \mathrm{~m}$ dengan cara zig-zag atau (selang seling). Pengambilan data di setiap stasiunnya terdiri dari 3 sub stasiun.

Metode pengambilan data untuk persentase tutupan karang menggunakan metode Line Intercept Transect (LIT). Pengambilan data tutupan karang dilakukan dengan cara membentangkan LIT tegak lurus dengan garis pantai dengan panjang $100 \mathrm{~m}$. Pengukuran terhadap bentuk pertumbuhan karang (life form) dilakukan pada karang yang bersinggungan dengan garis transek dan dicatat dengan ketelitian $\mathrm{cm}$. Mengidentifikasi bentuk pertumbuhan karang dengan menggunakan buku panduan buku Metedologi Pengambilan Karang.

Pengukuran parameter kualitas perairan dilakukan secara insitu yang bertujuan untuk mengetahui kondisi perairan habitat makroalga yang meliputi; pengukuran parameter fisika yaitu suhu, kedalaman, kecerahan, kecepatan arus dan untuk parameter kimia yaitu salinitas dan $\mathrm{pH}$.

Kepadatan adalah jumlah individu persatuan luas. Kepadatan masingmasing jenis pada setiap stasiun dihitung dengan menggunakan rumus Odum, (1993) :

$\mathrm{D}_{\mathrm{i}}=\frac{n_{i}}{\mathrm{~A}}$

Keterangan :

$\mathrm{D}_{\mathrm{i}}=$ Kepadatan makroalga (ind $/ \mathrm{m}^{2}$ )

$\mathrm{n}_{\mathrm{i}}=$ Jumlah total individu (individu)

$\mathrm{A}=$ Luas daerah yang disampling $\left(\mathrm{m}^{2}\right)$

Keanekaragaman jenis makroalga

dihitung dengan menggunakan persamaan Odum, (1993) sebagai berikut:

$H^{\prime}=-\sum_{i=1}^{i} P i \operatorname{Ln} P$

Keterangan :
$\mathrm{H}^{\prime}=$ Indeks keanekaragaman Jenis

$\mathrm{Pi}=$ Kelimpahan relatif ke-i

$\mathrm{ni}=$ Jumlah individu jenis

$\mathrm{N}=$ Jumlah individu keseluruhan

Tabel 2. Indeks Keanekaragaman Jenis Makroalga (Odum, 1993)

\begin{tabular}{cc}
\hline Kisaran & Keanekaragaman \\
\hline $\mathrm{H}^{\prime}<1$ & Rendah \\
$1<\mathrm{H}^{\prime} \leq 3$ & Sedang \\
$\mathrm{H}^{\prime}>3$ & Tinggi \\
\hline
\end{tabular}

Keseragaman dapat dikatakan sebagai keseimbangan, yaitu komposisi individu tiap jenis yang terdapat dalam suatu komunitas. Untuk menghitung keseragaman jenis dapat dihitung dengan menggunakan rumus Odum, (1993) berikut:

$\mathrm{E}=\frac{\mathrm{H}^{\prime}}{\mathrm{H}_{\max }}$

Keterangan:

$\mathrm{E} \quad=$ Indeks keseragaman

$\mathrm{H}^{\prime} \quad=$ Indeks keanekaragaman

$\mathrm{H}_{\max }=$ Keanekaragaman spesies maksimum $(\ln S)$

Kisaran Nilai Indeks

Keseragaman disajikan pada Tabel 3.

Tabel 3. Kisaran Nilai Indeks

Keseragaman (Odum, 1993)

\begin{tabular}{cl}
\hline Kisaran & \multicolumn{1}{c}{ Kategori } \\
\hline \multirow{2}{*}{$\mathrm{E}<0,4$} & Tingkat \\
& Keseragaman \\
& Populasi Kecil \\
\hline \multirow{3}{*}{$0,<\mathrm{E}<0,6$} & Tingkat \\
& Keseragaman \\
& Populasi Sedang \\
\hline \multirow{2}{*}{$\mathrm{E}>0,6$} & Tingkat \\
& Keseragaman \\
& Populasi Besar \\
\hline
\end{tabular}

Indeks dominansi dihitung dengan menggunakan rumus Odum, (1993) sebagai berikut:

$\mathrm{D}=\sum(\mathrm{ni} / \mathrm{N})^{2}$

Keterangan:

D = Indeks dominansi

ni $=$ Jumlah individu spesies ke- $\mathrm{i}$

$\mathrm{N}=$ Jumlah total spesies 
Tabel 4. Kisaran Nilai Indeks Dominansi (Odum, 1993)

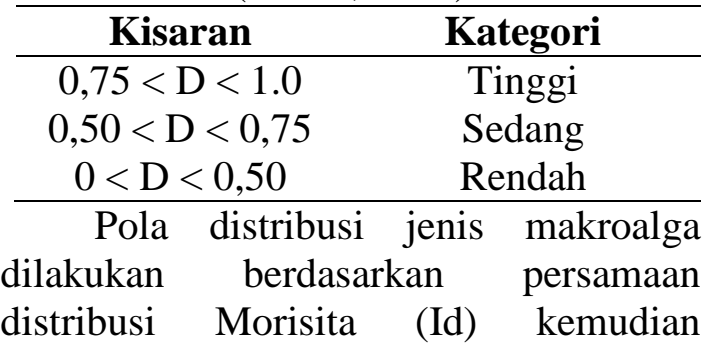
makroalga diidentifikasi dan dibuat hasil identifikasi jenis makroalga tersebut pada setiap stasiun pengamatan dalam bentuk tabel. Berikut persamaan pola sebaran Morisita (Id) menurut Brower dan Von, (1990):

$\mathrm{Id}=n \frac{\sum x^{2}-N}{N(N-1)}$

Keterangan:

Id = Indeks dispersi morisita

$\mathrm{n}=$ Jumlah plot pengambilan contoh

$\mathrm{N}=$ Jumlah individu total dalam plot

$\mathrm{X}^{2}=$ Jumlah individu pada setiap plot ke-i
Tabel 5. Kriteria Distribusi Jenis Makroalga (Id) (Brower dan Von, 1990)

\begin{tabular}{ll}
\hline Kisaran & \multicolumn{1}{c}{ Kriteria } \\
\hline Id $=1,0$ & $\begin{array}{l}\text { Pola penyebaran individu } \\
\text { acak }\end{array}$ \\
Id $<1,0$ & $\begin{array}{l}\text { Pola penyebaran individu } \\
\text { merata }\end{array}$ \\
Id $>1,0$ & $\begin{array}{l}\text { Pola penyebaran individu } \\
\text { mengelompok }\end{array}$ \\
\hline
\end{tabular}

Persentase tutupan lamun dapat di hitung dengan menggunakan persamaan (Setyobudiandi et al., 2009).

$\mathrm{C}=\frac{\Sigma(\mathrm{Ci})}{N}$

Keterangan :

$\mathrm{C}=$ Persentase penutupan lamun pada setiap stasiun

$\mathrm{Ci}=$ Persentase penutupan lamun jeni kei pada tiap plot transek

$\mathrm{A}=$ Jumlah plot transek setiap substasiun

Tabel 6. Status Padang Lamun (KEPMEN LH No. 200 Tahun 2004)

\begin{tabular}{ccc}
\hline Persentase Tutupan $(\%)$ & Status & Kondisi \\
\hline$>60$ & Baik & Kaya/sehat \\
$30-59,9$ & Rusak & Kurang kaya/kurang sehat \\
$<29,9$ & Rusak & Miskin \\
\hline
\end{tabular}

Persentase tutupan karang dapat dihitung dengan menggunakan persamaan (English et al.,1994).

$\mathrm{PC}=\frac{L i}{\text { Ltotal }} \times 100 \%$

Keterangan :

$\mathrm{PC}=$ Persentase tutupan karang $(\%)$

$\mathrm{Li}=$ Panjang tutupan life form $(\mathrm{m})$

$\mathrm{L}=$ Panjang tutupan transek $(\mathrm{m})$

Tabel 7. Kategori Tutupan Karang (Gomes dan Yap, 1984)

\begin{tabular}{cc}
$\begin{array}{c}\text { Persentase } \\
\text { Tutupan Karang } \\
(\boldsymbol{\%})\end{array}$ & $\begin{array}{c}\text { Kondisi } \\
\text { Terumbu } \\
\text { Karang }\end{array}$ \\
\hline $0-24,9$ & Buruk \\
$25-49,9$ & Sedang \\
$50-74,9$ & Baik \\
$75-100$ & Baik sekali \\
\hline
\end{tabular}

\section{Hasil dan Pembahasan}

Jenis makroalga yang ditemukan di lokasi penelitian berjumlah 12 jenis yaitu 1 jenis dari kelas Chlorophyta, 4 jenis dari kelas Phaeophyta, dan 7 jenis dari kelas Rhodophyta. Jenis yang paling banyak yaitu $D$. dichotoma dan yang paling sedikit yaitu jenis $A$. fraglilisima (Tabel 8). Pada stasiun I ditemukan 7 jenis makroalga yaitu $C$. decorticatium, $P$. australis, D. dichtoma, S. polycytum, T. ornota, G. dura dan G. ferguisonni. Pada stasiun II ditemukan 8 jenis makroalga yaitu $T$. ornota, $S$. polycytum, G. ferguisonni, G. coronopifolia, $\quad G$. textori, A. fraglilissima, S. hydnoides, Spermothmnion sp..

Jenis makroalga yang ditemukan pada stasiun II tidak jauh berbeda dengan 
stasiun I. Dimana, stasiun II terdapat 8 jenis makroalga dan stasiun I terdapat 7 jenis makroalga. Stasiun II terletak di daerah rataan terumbu karang, dan karang mati dengan tekstur substrat pecahan karang sehingga makroalga yang terdapat di daerah tersebut memiliki keanekaragaman jenis makroalga yang melimpah. Yudasmara, (2011) yang menyatakan bahwa, karang dapat menjadi media hidup alga karena sebagian besar makroalga hidup dengan cara menempel, terutama pada substrat yang keras seperti pecahan karang (rubble), karang mati serta benda-benda keras yang terendam di dasar laut.

Stasiun I terletak pada daerah lamun dan memiliki tekstur substrat berpasir sehingga kurangnya jenis makroalga yang diperoleh. Handayani dan Kadi (2007), variasi tekstur substrat perairan dapat mempengaruhi variasi jenis makroalga yang tumbuh dan perairan yang memiliki tekstur substrat berpasir berlumpur hanya terdapat beberapa jenis makroalga. Selanjutnya Kadi (2009), kehadiran jenisjenis makroalga menunjukan kombinasi struktur substrat sangat menentukan variasi jenis makroalga yang ada, di substrat pasir kebanyakan di tumbui oleh marga Halimeda, Gracilaria, Dictyota dan Amphiroa.

Hasil penelitian yang dilakukan di Perairan Desa Wawatu ditemukan sedikit jenis makroalga dibandingkan dengan hasil penelitian yang dilakukan oleh Ali (2010) di Perairan Lakeba Kota Bau Bau diperoleh 16 jenis makroalga, 5 jenis kelas Chlorophyta, 5 jenis dari kelas Rhodophyta dan 6 jenis dari kelas Phaeophyta. Jenis makroalga pada perairan tersebut lebih banyak ditemukan dari kelas Phaeophyta disebabkan oleh tekstur substrat yang berpasir dan pecahan karang mati. Sedangkan penelitian yang dilakukan oleh Ariani (2016) di Perairan Desa Lalowaru Kecamatan Moramo Utara diperoleh makroalga sebanyak 16 jenis, 5 jenis dari kelas Chlorophyta, 6 jenis dari kelas Rhodophyta dan 5 jenis dari kelas Phaephyta yang ditemukan pada susbstrat berpasir dan pecahan karang. Menurut Papalia dan Arfah (2013), perbedaan jumlah jenis makroalga pada setiap lokasi penelitian diduga disebabkan oleh perbedaan habitat dan musim, umumnya makroalga tumbuh pada habitat berupa karang mati dan pasir.

Tabel 8. Jenis dan Jumlah Makroalga pada Lokasi Penelitian

\begin{tabular}{|c|c|c|c|}
\hline \multirow[b]{2}{*}{ No. } & \multirow[b]{2}{*}{ Jenis Makroalga } & \multicolumn{2}{|c|}{ Jumlah Individu Makroalga } \\
\hline & & Stasiun I & Stasiun II \\
\hline \multirow{3}{*}{1.} & Kelas Chlorophyta (alga hijau) & & \\
\hline & Codium decorticatum & 101 & - \\
\hline & Kelas Phaeophyta (alga coklat) & & \\
\hline 2. & Padina australis & 266 & - \\
\hline 3. & Dictyota dichotoma & 281 & - \\
\hline 4. & Sargassum polycytum & 110 & 21 \\
\hline \multirow[t]{2}{*}{5.} & Turbinaria ornota & 69 & 38 \\
\hline & Kelas Rhodophyta (alga merah) & & \\
\hline 6. & Gracilaria dura & 125 & - \\
\hline 7. & Gracilaria ferguisonni & 177 & 208 \\
\hline 8 & Gracilaria coronopifolia & & 88 \\
\hline 9. & Gracilaria textori & - & 58 \\
\hline 10. & Amphiroa fraglilissima & - & 51 \\
\hline 11. & Sympiloca hydnoides & - & 57 \\
\hline \multirow[t]{2}{*}{12.} & Spermothamnion sp. & - & 121 \\
\hline & Jumlah & 1069 & 642 \\
\hline
\end{tabular}


Tabel 9. Hasil Perbandingan Penelitian Lain di Sulawesi Tenggara

\begin{tabular}{|c|c|c|c|c|c|}
\hline \multirow[t]{2}{*}{ No. } & \multicolumn{3}{|c|}{ Kelas Makroalga } & \multirow[t]{2}{*}{ Lokasi } & \multirow[t]{2}{*}{ Peneliti } \\
\hline & Chlorophyta & Rhodophyta & Phaeophyta & & \\
\hline 1. & 5 Jenis & 5 Jenis & 6 Jenis & $\begin{array}{l}\text { Perairan Lakeba, Bau- } \\
\text { bau }\end{array}$ & $\begin{array}{l}\text { Fadillah } \\
\text { Ali (2010) }\end{array}$ \\
\hline 2. & 5 Jenis & 3 Jenis & 5 Jenis & $\begin{array}{l}\text { Desa Lalowaru, } \\
\text { Moramo Utara }\end{array}$ & $\begin{array}{l}\text { Ariani } \\
(2016)\end{array}$ \\
\hline 3. & 3 Jenis & 1 Jenis & 1 Jenis & $\begin{array}{l}\text { Perairan Tanjung } \\
\text { Tiram }\end{array}$ & $\begin{array}{l}\text { Farito et } \\
\text { al., (2018) }\end{array}$ \\
\hline 4. & 3 Jenis & 2 Jenis & 5 Jenis & $\begin{array}{l}\text { Perairan Waworaha } \\
\text { Kecamatan Soropia }\end{array}$ & $\begin{array}{l}\text { Rosdiana } \\
(2017)\end{array}$ \\
\hline
\end{tabular}

Hasil penelitian yang dilakukan oleh Farito et al. (2018) di Perairan Desa Tanjung Tiram Kecamatan Moramo Utara menemukan 5 jenis makroalga, 3 jenis dari kelas Chlorophyta, 1 jenis dari kelas Phaeophyta dan 1 jenis dari kelas Rhodophyta. Makroalga yang ditemukan di perairan ini lebih dominan pada jenis makroalga dari kelas Chlorophyta disebabkan oleh jenis substrat terumbu karang buatan dari sampah plastik. Sedangkan penelitian yang dilakukan oleh Rosdiana (2017) di Perairan Waworaha Kecamatan Soropia menemukan 10 jenis makroalga, 3 jenis dari kelas Chlorophyta, 2 jenis dari kelas Rhodophyta, dan 5 jenis dari kelas Phaeophyta. Makroalga yang ditemkan pada perairan tersebut lebih banyak ditemukan makroalga dari kelas Phaeophyta hal ini karena disebabkan oleh tekstur substrat yang pasir berlempung dan pecahan karang.

Kepadatan makroalga pada stasiun I dan II menunjukan jumlah kepadatan pada setiap stasiun berbeda. Pada stasiun I diperoleh $35,633 \mathrm{ind} / \mathrm{m}^{2}$ dengan jumlah 7 jenis makroalga sedangkan pada stasiun II diperoleh 21,4 $\mathrm{ind} / \mathrm{m}^{2}$ dengan jumlah 8 jenis makroalga (Tabel 10). Berdasarkan hasil penelitian yang telah dilakukan, makroalga yang paling sering ditemukan pada kedua stasiun yaitu $G$. ferguisonni dari kelas Rhodophyta. Hal tersebut dikarenakan substrat tempat melekatnya makroalga pada rataan terumbu karang, pecahan karang dan berpasir. Hal ini sesuai dengan pernyataan Kadi (2004), kepadatan makroalga sangat dipengaruhi oleh pergantian musim dan kondisi substrat dasar paparan terumbu yang stabil akan menyebabkan penyebaran jenis yang rendah serta adanya individu yang dominan. Kepadatan suatu organisme ditentukan oleh kemampuan menyesuaikan diri dengan lingkungan tempat organisme itu hidup.

Tabel 10. Kepadatan Jenis Makroalga di Perairan Desa Wawatu

\begin{tabular}{cc}
\hline Stasiun & $\begin{array}{c}\text { Kepadatan Jenis } \\
\text { Makroalga }\left(\text { Ind } / \mathbf{m}^{\mathbf{2}}\right)\end{array}$ \\
\hline I & 35,633 \\
II & 21,4 \\
\hline
\end{tabular}

Zulfia (2016), menyatakan bahwa kelas Rhodophyta memiliki toleransi yang baik terhadap ombak yang terdapat didaerah pasang surut dibandingkan dengan jenis makroalga lainnya. Raven et al. (2005), dalam penelitiannya menjelaskan bahwa holdsfat merupakan sistem akar pada tanaman yang berfungsi sebagai jangkar alga pada substrat dimana ia tumbuh, dengan demikian akan mencegah alga terbawa arus.

Perbedaan jumlah kepadatan makroalga yang ditemukan disetiap stasiun dipengaruhi oleh kemampuan adaptasi dari jenis makroalga, selain itu juga disebabkan oleh kondisi lingkungan seperti kedalaman dan kecerahan untuk melakukan fotosintesis. Kedalaman pada stasiun I yaitu 1,2 $\mathrm{m}$ dan stasiun II yaitu $2,5 \mathrm{~m}$ dengan kecerahan $100 \%$. 
Perbedaan kepadatan jenis makroalga pada setiap stasiun juga dipengaruhi oleh tipe substrat yang berbeda seperti pada stasiun I yaitu substrat pasir. Pada stasiun II yaitu rataan terumbu karang dan karang mati. Yudasmara (2011), menyatakan bahwa perbedaan kepadatan dari masing-masing makroalga sangat dipengaruhi oleh beberapa faktor diantaranya daya reproduksi yang tinggi, kemampuan adaptasi yang lebih berkembang, daya tahan yang lemah terhadap habitat, adanya predator dan penyakit atau keadaan lingkungan yang kurang mendukung. Ayhuan et al. (2017), menyatakan bahwa kepadatan pada masing-masing lokasi diduga karena berkaitan dengan kondisi fisik abiotiknya seperti tipe substrat, kecerahan, sirkulasi kecepatan arus, nutrien, adaptasi dengan lingkungan makroalga itu sendiri.

$$
\text { Indeks keanekaragaman }
$$

merupakan salah satu struktur komunitas yang digunakan untuk menentukan keanekaragaman jenis organisme di suatu perairan. Indeks keanekaragaman jenis makroalga stasiun I yaitu 1,824 dan stasiun II yaitu 1,864 (Tabel 11). Indeks keanekaragaman di Perairan Desa Wawatu menunjukan keanekaragaman yang sedang dengan kisaran stabilitas $1<\mathrm{H}^{\prime} \leq 3$ (Odum, 1993).

Stasiun I memiliki nilai indeks keanekaragaman lebih sedikit dibanding stasiun II, pada stasiun I hanya terdapat 7 jenis makroalga dengan jumlah total 1069 individu. Sedangkan pada stasiun II terdapat 8 jenis makroalga dengan jumlah total 642 individu. Perbedaan indeks keanekaragaman makroalga dipengaruhi oleh jumlah individu seluruh jenis makroalga. Selain itu substrat juga merupakan salah satu faktor yang menyebakan perbedaan jumlah keanekaragaman yang terdapat pada setiap stasiun, yaitu pada stasiun I memiliki jenis substrat berpasir sedangkan pada stasiun II jenis substrat rataan terumbu karang dan pecahan karang. Sukiman (2014), menyatakan bahwa keseragaman makroalga pada masing-masing perairan menggambarkan jumlah dan keanekaragaman spesies makroalga yang dapat beradaptasi pada konsisi habitat tersebut. Fachrul (2007), juga menyatakan bahwa suatu komunitas umumnya terdapat berbagai jenis tumbuhan maka semakin stabil keadaan suatu komunitas maka semakin tinggi keanekaragaman jenis tumbuhannya. Selanjutnya Romimohtarto dan Juwana (2005), yang menyatakan bahwa keanekaragaman jenis makroalga ditentukan pula oleh keanekaragaman habitat (substrat), di tempat yang memiliki substrat pecahan karang batu mati, karang masif dan pasir yang lebih stabil mempunyai keanekaragaman alga yang lebih tinggi dibandingkan dengan tempat yang hanya bersubsrat pasir dan lumpur.

Tabel 11. Indeks Keanekaragaman Jenis (H'), Indeks Keseragaman (E), dan Indeks Dominansi (D) Makroalga pada Lokasi Penelitian

\begin{tabular}{ccccccc}
\hline Stasiun & H' & Kategori H' & E & Kategori E & D & Kategori D \\
\hline I & 1,824 & Sedang & 0,937 & Besar & 0,180 & Rendah \\
II & 1,864 & Sedang & 0,896 & Besar & 0,186 & Rendah \\
\hline
\end{tabular}

Tabel 12. Distribusi Jenis Makroalga (Id) pada Lokasi Penelitian

\begin{tabular}{ccc}
\hline Stasiun & Pola Distribusi (Id) & Kategori \\
\hline I & 0,168 & Merata \\
II & 0,412 & Merata \\
\hline
\end{tabular}


Keberadaan makroalga di perairan ini didukung oleh faktor lingkungan lain seperti suhu, salinitas dan $\mathrm{pH}$. Nilai suhu diperoleh $29-30^{\circ} \mathrm{C}$, salinitas yaitu $35 \mathrm{ppt}$, dan $\mathrm{pH}$ perairan pada kedua stasiun tersebut diperoleh sebesar 7. Hal ini sesuai dengan pernyataan Papalia dan Arafah (2013), menyatakan bahwa parameter kualitas air yang tercatat selama penelitian masih berada pada kisaran yang layak mendukung pertumbuhan makroalga, dimana suhu berkisar antara $27,4-29,5^{\circ} \mathrm{C}$ dengan $\mathrm{pH}$ berkisar antara 7,0-8,5. Menurut Arafah dan Patty (2014), nilai salinitas yang baik untuk pertumbuhan makroalga berkisar antara 28-34 ppt. Berdasarkan hasil analisis indeks dominansi makroalga pada stasiun I yaitu 0,180 dan stasiun II yaitu 0,186 (Tabel 11). Nilai dominansi pada stasiun I dan II dikategorikan rendah. Berdasarkan kisaran indeks dominansi $0<\mathrm{D}<0,50$ (Odum, 1993). Maka dapat disimpulkan bahwa makroalga pada Perairan Desa Wawatu tidak ada jenis makroalga tertentu yang mendominansi hal ini disebabkan oleh faktor keanekaragaman jenis makroalga yang lebih tinggi yaitu pada stasiun I 7 jenis makroalga dan stasiun II 8 jenis makroalga. Ferawati et al. (2014), menyatakan bahwa suatu komunitas apabila terdapat organisme dengan tingkat dominansi yang rendah maka keanekaragaman menjadi tinggi.

Tinggi rendahnya nilai dominansi dipengaruhi oleh rendah dan tingginya nilai keanekaragaman jenis makroalga. Mackenzie et al. (1998), menyatakan bahwa ada hubungan antara keanekaragaman dan dominansi jenis berbanding terbalik, dimana daerah yang mempunyai tingkat dominansi rendah akan mempunyai tingkat keanekaragaman yang tinggi.

Pola Distribusi jenis makroalga dibedakan atas tiga kriteria yaitu pola penyebaran secara acak, merata dan mengelompok. Berdasarkan hasil penelitian yang telah dilakukan pada stasiun I yaitu 0,168 dan stasiun II yaitu 0,412 (Tabel 12). Berdasarkan kisaran distribusi jenis makroalga dikategorikan merata Id<1,0 (Brower dan Von, 1990). Pola distribusi jenis makroalga yang merata dipengaruhi oleh faktor lingkungan dan faktor biologis makroalga. Dimana makroalga menggunakan holdfast sebagai alat untuk melekat pada substrat. Hal inilah yang menimbulkan perbedaan dalam kekayaan spesies dan sebaran makroalga pada suatu tempat dengan tempat yang lain (Kadi, 2005).

Keanekaragaman jenis makroalga dan tipe substrat dapat mempengaruhi tingginya pola distribusi makroalga di Perairan Desa Wawatu. Menurut Kadi (2004), pola sebaran makroalga disebabkan oleh faktor ekologi perairan yang dapat mengontrol keberadaan makroalga dan karasteristik biologis makroalga. Kehadiran spesies di suatu wilayah ditentukan oleh faktor karakteristik lingkungan dan karakteristik makroalga itu sendiri. Kesesuaian antara kedua faktor tersebut akan menentukan pertumbuhan makroalga termasuk kemampuan menempel pada tahap awal pertumbuhannya.

Pola distribusi makroalga yang merata disebabkan oleh faktor lingkungan yaitu kedalaman dan kecerahan perairan dalam hal ini berkaitan dengan proses masuknya cahaya matahari hingga dasar perairan. Kedalaman perairan pada stasiun I yaitu 1,2 $\mathrm{m}$ dan stasiun II 2,5 $\mathrm{m}$ dan kecerahan stasiun I dan II yaitu $100 \%$. Kondisi perairan ini masih dapat ditembus oleh cahaya matahari yang merupakan salah satu faktor yang membantu makroalga fotosintesis di perairan. Hal ini sesuai pertanyaan Irwandi et al. (2017), bahwa kecerahan perairan menunjukan bahwa kecerahan perairan menunjukan kemampuan cahaya lapisan air pada Kedalaman tertentu, dimana kecerahan sangat penting karena erat kaitannya dengan proses fotosintesis. 
Tabel 13. Persen Penutupan Lamun (C) pada Lokasi Penelitian

\begin{tabular}{lc}
\hline Jenis Lamun & Persen Penutupan (\%) \\
\hline T. hemprichii & 31,291 \\
C. acoroides & 20,291 \\
S. isoetifolium & 12,708 \\
H. ovalis & 3,708 \\
\hline Jumlah Total & $\mathbf{6 7 , 9 9 8}$ \\
\hline
\end{tabular}

Tabel 14. Distribusi Jenis Makroalga berdasarkan Habitat pada Ekosistem Lamun dan Karang

\begin{tabular}{|c|c|c|c|}
\hline \multirow[b]{2}{*}{ Jenis Makroalga } & \multicolumn{2}{|c|}{ Ekosistem } & \multirow{2}{*}{ Distribusi Habitat } \\
\hline & Lamun & Karang & \\
\hline \multicolumn{4}{|l|}{ Chlorophyta (alga hijau) } \\
\hline Codium decorticatum & $\sqrt{ }$ & - & $\begin{array}{l}\text { Melekat pada substrat dasar di } \\
\text { padang lamun }\end{array}$ \\
\hline \multicolumn{4}{|l|}{ Phaeophyta (alga coklat) } \\
\hline Padina australis & $\sqrt{ }$ & - & $\begin{array}{l}\text { Melekat pada substrat berpasir dan } \\
\text { terumbu karang yang mati }\end{array}$ \\
\hline Dictyota dichotoma & $\sqrt{ }$ & - & Melekat pada substrat berpasir \\
\hline Sargassum polycytum & $\sqrt{ }$ & $\sqrt{ }$ & $\begin{array}{l}\text { Melekat pada substrat berpasir dan } \\
\text { rataan terumbu karang }\end{array}$ \\
\hline Turbinaria ornota & $\sqrt{ }$ & $\sqrt{ }$ & $\begin{array}{l}\text { Menancap pada substrat berpasir } \\
\text { dan rataan terumbu karang }\end{array}$ \\
\hline \multicolumn{4}{|l|}{ Rhodophyta (alga merah) } \\
\hline Gracilaria dura & $\sqrt{ }$ & - & $\begin{array}{l}\text { Melekat pada substrat berpasir dan } \\
\text { rataan terumbu karang }\end{array}$ \\
\hline Gracilaria ferguisonni & $\sqrt{ }$ & $\sqrt{ }$ & $\begin{array}{l}\text { Melekat pada substrat berpasir dan } \\
\text { terumbu karang yang mati }\end{array}$ \\
\hline Gracilaria coronopifolia & & $\sqrt{ }$ & $\begin{array}{l}\text { Melekat pada batu di rataan } \\
\text { terumbu karang }\end{array}$ \\
\hline Gracilaria textori & - & $\sqrt{ }$ & $\begin{array}{l}\text { Melekat pada batu di rataan } \\
\text { terumbu karang }\end{array}$ \\
\hline Amphiroa fraglilissima & - & $\sqrt{ }$ & Melekat pada terumbu karang mati \\
\hline Sympiloca hydnoides & - & $\sqrt{ }$ & $\begin{array}{l}\text { Melekat pada batu di rataan } \\
\text { terumbu karang }\end{array}$ \\
\hline Spermothamnion sp. & - & $\sqrt{ }$ & Melekat pad terumbu karang mati \\
\hline
\end{tabular}

Kehidupan makroalga dengan padang lamun dan karang hidup saling berdampingan dimana masih terdapat cahaya matahari yang cukup untuk melakukan fotosintesis. Karateristik keanekaragaman habitat seperti substrat (berpasir, berbatu, rataan terumbu karang dan karang mati), kedalaman, salinitas, $\mathrm{pH}$, kecepatan arus dan kondisi padang lamun maupun karang yang baik juga mempengaruhi kehidupan dan keberadaan makroalga disuatu perairan. Romimohtarto dan Juwana (2005), keberadaan jenis makroalga ditentukan pula oleh keanekaragaman habitat (substrat), di tempat yang memiliki substrat pecahan karang batu mati, karang masif dan pasir yang lebih stabil mempunyai keanekaragaman alga yang lebih tinggi dibandingkan dengan tempat yang hanya bersubsrat pasir dan lumpur. 


\section{Simpulan}

Berdasarkan hasil penelitian yang telah dilakukan di Perairan Desa Wawatu dapat disimpulkan yaitu sebagai berikut:

1. Jenis makroalga yang ditemukan di Perairan Desa Wawatu yaitu, pada ekosistem lamun 1 jenis kelas Chlorophyta (C. decorticatum), 4 jenis kelas Phaeophyta ( $P$. australis, $D$. dichotoma, $S$. polycytum, $T$. ornota) dan 2 jenis kelas Rhodophyta (G. dura dan G. ferguisonni). Pada ekosistem karang 2 jenis kelas Phaeophyta (S. polycytum, T. ornota) dan 6 jenis kelas Rhodophyta (G. ferguisonn, G. coronopifolia, $G$. textori, A. fraglilissima, S. hydnoides, Spermothamnion sp.).

2. Pola distribusi jenis makroalga pada ekosistem lamun dan karang di Perairan Desa Wawatu yaitu merata.

\section{Daftar Pustaka}

Ali, F. 2010. Studi Ekologi Makroalga (sea weed) di Perairan Lakeba Kota Bau-Bau. Universitas Halu Oleo. Kendari.

Arfah, H. dan Patty, S. I. 2014. Keanekaragaman dan Biomassa Makroalga di Perairan Teluk Kotania, Seram Barat. LIPI. Jakarta.

Ariani, 2016. Komposisi dan Distribusi Makroalga Berdasarkan Tipe Substrat di Perairan Desa Lalowaru Kecamatan Moramo Utara. Universitas Halu Oleo. Kendari.

Atmadja, W. S., Kadi, A., Sulistijo, S. dan Rachmaniar. 1996. Pengenalan Jenis-Jenis Rumput Laut Indinesia. Oseanoligi- LIPI. Jakarta

Ayhuan, H. V., Zamani. N. P. dan Soedharmo, D. 2017. Analisis Struktur Komunitas Makroalga Ekonomis Penting di Perairan Intertidal Manokwari, Papua Barat. Insitup Pertanian Bogor. Bogor.

Brower, J. E. J. H. Z. dan Von C. E. 1990. Ekologi Umum. Metode Lapangan dan Laboratorium. Wm.
C. Brown Company Publisher, Dubuque, Iowa.

Direktorat Jendral Perikanan. 1997. Atlas Sumber Daya Kelautan. Badan Koordinasi Survey dan Pemetaan Nasional.

Eglish, S. C., Wikinsom. dan V. Baker. 1994. Survey Manual for Tropical Marine Resources. Australia Insitut of Marine Science. Townsville, 368 Hal.

Fachrul, M, F. 2007. Metode Sampling Bioekologi. Penerbit Bumi Aksara. Jakarta.

Farito., Kasim, M. dan Nur, I. A. 2018. Studi Kepadatan Dan Keanekaragaman Makroalga pada Terumbu Karang Buatan dari Sampa Plastik di Perairan Desa Tanjung Tiram Kecamatan Moramo Utara Kabupaten Konawe Selatan. Jurnal Menejemen Sumber Daya Perairan. 3(2): 93-103

Ferawati, E., Widyartini, D. S. dan Insan, I. 2014. Studi Kommunitas Rumput Laut pada berbagai Substrat di Perairan Pantai Permisan Kabupaten Cilacap. UniversitasJendral Soedirman. Purwekerto.

Gomez, E. D. dan Yap, H. 1984. Monitoring Reef Condition. Unesco.

Handayani, T. dan Kadi, A. 2007. Keanekaragaman dan Biomassa Agae di Perairan Minahasa Utara, Sulawesi Utara. Pusat Penelitia Oseanografi LIPI. Jakarta.

Irwandi., Salwiyah. dan Nurgayah, W. 2017. Stuktur Komunitas Makroalga pada Substrat yang berbeda di Perairan Desa Tanjung Tiram Kecamatan Moramo Utara Kabupaten Konawe Selatan Provinsi Sulawesi Tenggara. Jurnal Menejemen Perairan. 2(3). 215-224 hal.

Jha, B., Raddy, C. K. R., Thakur, M. C. dan Rao, M. U. 2009. Seaweeds of India the Diversity and 
Distributions of seaweeds of the Gujarat Coarst.

Kadi, A. 2005. Makroalgae di Perairan Kepulauan Bangka, Belitungdan Karimata. Jour. Mar. Sci. Univ. Diponegoro.

Kadi, A. 2009. Makroalga di Paparan Terumbu Karang Kepulauan Anambas. Pusat Penelitian Oseanografi LIPI. Jakarta.

Kadi, A. 2004. Potensi Rumput Laut Dibeberapa Perairan Pantai Indonesia. Oseana. Pusat Penelitian Oseanografi LIPI. Jakarta.

Keputusan Menteri Lingkungan Hidup Nomor 4 dan 200 Tahun 2004. Kriteria Baku Kondisi Kerusakan Terumbu Karang. Deputi MENLH Bidang Kebijakan dan Kelembagaan Lingkungan Hidup.

Luning. 1990. Seaweeds, Their Environment, Biogeography and Ecophysiology. John Wiley and Sons. New York.

Mackenzie, A., Ball, A. S. dan Virdee, S. R. 1998. Instant Notes in Ecology. Singapore: Bios. Scientific Publisher.

Mackenzie., Campbell, S. J. dan Roder, C. A. 2003. Seagrasswatch: Manual for Mapping and Monitoring Seagrass Resources by Community (Citizen). Volunteres 2sd edition. The Satate of Queensland, Depertemen of Primay Industries, CRC Reef. Queensland. 104 hal.

Ningsi, D. 2006. Struktur Komunitas Alga Laut Makrobentik di Pantai TNB Jamber.

Nybakken, J. W. 1992. Biologi Laut Suatu Pendekatan Ekologis. PT. Gramedia. Jakarta.

Odum, E. P. 1993. Fundamental of ecology. Gajamada University Press. Yogyakarta

Papalia, S. dan Arfah H. 2013. Produktivitas Biomasa Makroalga di Perairan Pulau Ambalau, Kabupaten Buru Selatan. Jurnal
Ilmu dan Teknologi Kelautan Tropis. (5)2: 465-477.

Raven., Peter, H., Ray, F., Evert. Dan Susan, E. E. 2005. Biology of Plants, $7^{\text {th }}$ ed. New York: W.H. Freeman and Company Publishers. 119-127 hal.

Romimohtarto, K. dan Juwana, S. 2005. Biologi Laut. Ilmu Pengetahuan Tentang Biota Laut. Penerbit Djambatan. Jakarta.

Rosdiana. 2017. Struktur Komunitas Makroalga di Perairan Waworaha Kecamatan Soropia. Universitas Halu Oleo. Kendari

Rusli. 2006. Tipologi Makroalga pada Ekosistem Terumbu Karang di Tiga Pulau Kawasan Pulau Seribu DKI Jakarta. Skripsi Institut Pertanian Bogor.

Salmin. 2005. Oksigen Terlarut (DO) dan Kebutuhan Oksigen Terlarut (BOD) Sebagai Salah Satu Indikator untuk Menentukan Kualistas Perairan. 21-26 hal.

Setyobudiandi, I., Sulistino, F., Yulianda, C., Kusuma, S., Hariyadi, A., Dammar, A. S. dan Bahtiar. 2009. Sampling dan Analisis Data Perikanan dan Kelautan. FPIK-IPB. Bogor.

Setyobudiandi. I., Soekendarsi, E., Juariah, U., Bahtiar., Hari., H. 2009. Sari Biota Laut Rumput Laut Indonesia Jenis dan Upaya Pemanfaatan. Unhalu Press. Kendari.

Sinyo, Y. dan Somardayo, N. 2013. Studi Keanekaragaman Jenis Makroalga di Perairan Pantai Pulau Dofamuel Sidangoli Kecamatan Jailolo Selatan Kabupaten Halmahera Barat. Unkhair Ternate.

Sukiman. 2014. Keanekaragaman dan Distribusi Spesis Makroalga di Wilayah Sekatong Lombok Barat. Jurnal Penelitian UNMRA. Vol. 18 (2).

Widyartini. D. S, Insan. I. A . H, dan Sulistyani. 2011. Keanakaragaman 
Spesies Rumput Laut Coklat Phaeophyceae Pada Substrat Karang Pantai Menganti Kebumen. Prosiding Seminar Nasional Hari Lingkungan.

www. Algabase.org

Yudasmara, A. 2011. Analisis Komunitas Makroalga di Perairan Pulau Menjangan Kawasan Taman Nasional Bali Barat. Disertasi. IPB Bogor.

Zulfia, F. A., Zafi, I. S., Mawaddah, K. dan Erinda, L. 2016. Keanekaragaman Makroalga Sekitar pantai pancur Alas Purwo Sebagai Media Pembelajaran Realita Mahasiswa Calon Guru Biologi di FMIPA Universitas Negeri Malang. Universitas Negeri Malang. 